\title{
Applications of Green Architecture in Vernacular Dwelling Architecture-A Case Study from Jordan
}

\author{
Mohannad Tarrad*, Saqer Sqour \\ Department of Architecture Engineering, Faculty of Engineering, Al-Bayt University, Mafraq 130040, Jordan
}

Corresponding Author Email: ms-tarrad@aabu.edu.jo

https://doi.org/10.18280/ijdne.150408

Received: 10 June 2020

Accepted: 17 July 2020

\section{Keywords:}

dwelling building, environmental architecture, vernacular architecture, green architecture, society community, Jordan

\begin{abstract}
Although the application of green architecture in Jordan is still limited but an urgent necessity and not a luxury, because of lack of energy and water resources in Jordan. This study focused on how to implement the green house and link it with dwelling vernacular architecture to provide realistic solutions appropriate to society and architects. The importance of the research comes by encouraging and stimulating the application of green architecture for dwelling in Jordan, after its slow implementation through global green architecture. As residents begin to complain about the modern multi-story dwelling building that does not include contact with nature and increases the electricity and water bill.
\end{abstract}

\section{INTRODUCTION}

Vernacular architecture in Jordan was one of the most important types of built architecture that depended on the surrounding and the traditions of the population. Although of that, it was difficult to maintain some types of past architecture due to the development in architecture.

Until recently, historical architecture was appropriated to the principles of sustainability because it depends on available resources and environmental technologies.

In the final years of the last century, the term 'sustainable development' began to be used. Sustainability is considered a prerequisite for the long-term viability of development efforts, although the term is still without an agreed upon procedural definition. Historical fact shows that nurturing the environment lies at the heart of sustainable development and that social, economic, political and technical considerations are necessary for sustainable development. Architecture conditions in the framework of sustainable development reflect the achievements of each era in the development of architecture; however, this is based on the relationship between architecture, culture and society and the use of developments in technology and architecture materials. This involves the use of renewable natural resources in a sustainable manner, which does not affect the ability of future generations to exploit these sources while preserving natural resources [1].

With regard to green building or environmentally friendly building, Jordan is one of the countries that have discussed how to apply green building standards, where there are more than five institutions looking in this field, including governmental, trade union and civil society institutions. In Jordan, there were and still are many studies on how to find a green building. The Ministry of Public Works issued a guide to green buildings in 2010, the Royal Society issued a study on the development of green architecture in Jordan in 2013 and the Jordanian Green Building Council was established in 2009 as the first professional non-profit and non-governmental association concerned and specialized in the concept of green buildings in Jordan, which is part From a global network. The Jordanian Council for Green Buildings has evolved to be a world leader in this field by spreading awareness about the green built environment, by encouraging the adoption of green principles and behaviors in Planning and design, and there is a clear interest from the Center for the Study of the Built Environment (CSBE), which was established in 1999, is a nonprofit research institution aiming to address the challenges that affect the built environment in Jordan and abroad. The environment of buildings, streets and open spaces. The latest studies were entitled "Contemporary Rural Dwellings in Jordan: Conception, Construction, Habitation, The Case Study of Umm al-Yanabi' Town [2].

\section{METHODOLOGY}

The research depended on the studying and analysis of vernacular dwelling architecture in Jordan and the related concepts, and depended also on comparison between dwelling architecture patterns in the past and now in an attempt to draw attention to the importance of environmental architecture in housing, especially with regard to the problems that have appeared in the current multi-storey dwelling architecture. The research analysed a dwelling house on which green architecture concepts were applied using ideas and local materials. The research assumes that the application of green architecture within the vernacular concept is more successful and creative than following green global architecture that is far from the culture of society, its behaviour, needs, economic capacity and ability to implement.

\section{AIM OF STUDY}

The idea of convincing the citizen, government and private institutions of the benefits of the green building was 
impossible in the beginning. This study came to highlight the lack of interest in applying green architecture to dwelling architecture despite teaching it in university courses in the architectural departments in Jordanian universities where the problem appeared clearly after COVID-19 crisis. Knowing that $72 \%$ of households do not own a garden [3], especially in major Jordanian cities such as Amman, Zarqa, and Irbid after the Jordanian government imposed a curfew and prevented citizens from leaving homes for a period of more than a month, and the Jordanian society needed a green building that meets their functional needs and that is connected with nature and has ventilation, views, good insulation and takes into account the feeling Enjoy and not be bored when sitting at home for long days.

\section{VERNACULAR HERITAGE DWELLING IN JORDAN}

Dwelling buildings can be defined as a type of architecture that adapts to details and plans involving human adaptation in different environments. In addition, it undergoes the civilized developments of time and place.

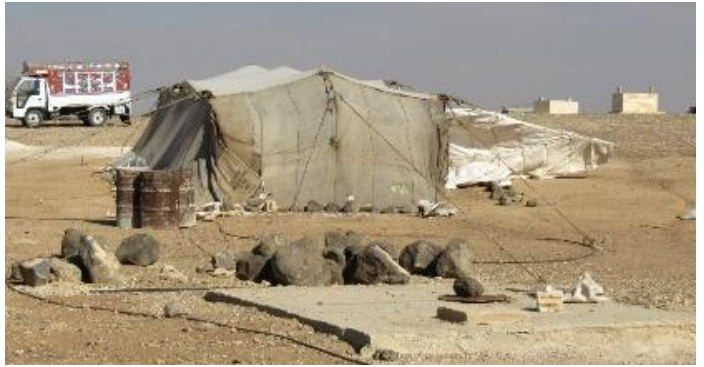

(A) Picture showing a stage of stability in the traditional house in semi-desert areas

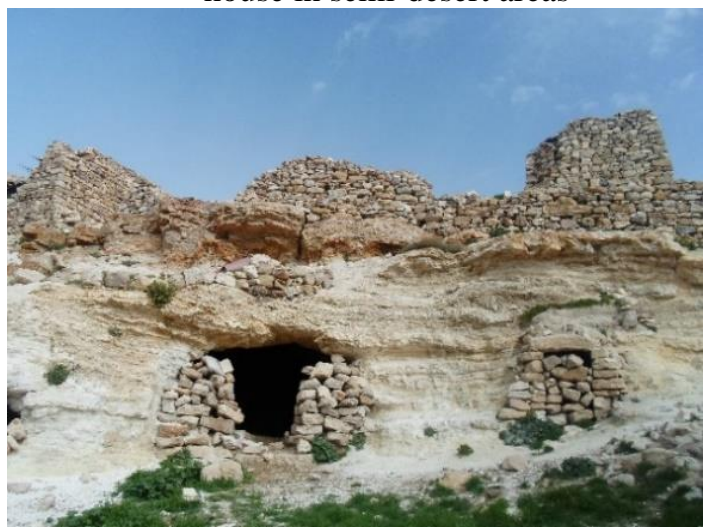

(B) Picture showing a stage of housing stability in Jordan in the mountainous region

Figure 1. The appropriateness of dwelling architecture for the environment in Jordan and how it evolved over time. (Source: by the author)

Housing is defined as an essential element of connection between the human, the family and the social environment. A dwelling building is a place that provides comfort and important functions. It creates an organizational pattern. A dwelling building is a space in which many family relationships grow and develop. Designing a Dwelling building is achieved based on two basic factors: the building and its inhabitants (the environment and the individual). Thus, a dwelling building is considered a type of architecture created to serve a complex group of purposes to serve its inhabitants and to build a civilized phenomenon. Its form and organization are greatly influenced by the civilization it belongs to as a miniaturized urban environment. Housing is the active function of a dwelling building that creates a better adapted environment for individuals in all respects and also creates a social unit of space.

Many styles of dwelling architecture have emerged, and each style is closely related to the environment, society and the materials and technical potential of the community. In particular, Jordan has changed the forms of dwelling construction and the various materials used in housing structures throughout history. It also involves the selection of architectural materials available in the environment that are suitable for the conditions of the use of housing. In the Stone Age, human was housed in caves within rocks and trees. The Bedouins invested in sheep, wool and leather to create tents, which could be dismantled and installed when there was the need to migrate. With the start of civilization and stability, man began to build dwelling buildings with stone and mud and used logs, branches and clay as roofs, as shown in Figure 1.

\section{VERNACULAR CONTEMPORARY DWELLINGS TYPES IN JORDAN}

Vernacular dwelling architecture in Jordan promotes stability and family formation. This is based on initial dwelling construction in which the traditional methods of architecture suitable for the environment were used. The vernacular architecture seems in its dwellings and harmony relationship with their surroundings and nature to attain good living conditions for their inhabitants [4]. Dwelling architecture in Jordan was mainly dependent on local craftsmen from Jordan or neighbouring countries, such as Syria or Palestine. Based on experiences local people learned from their grandparents, construction involved the materials available to them, which characterised architecture in Jordan, such as using local stone extracted from the land if the land was rocky. Architecture in Jordan is a traditional and vernacular architectural environment. Therefore, the community was built based on the culture of the people and their social relations through the formation of livestock and public spaces, linking them with the integrated local cultural fabric, especially in Jordanian villages. Vernacular Jordanian Dwelling architecture contains elements and technical treatments that are based on the environment because they were founded in accordance with climatic considerations in addition to social and cultural requirements. Traditional Arab architecture was generally characterised by simplicity and spontaneity and its direct harmony with special needs and environmental conditions. Urban growth was not based on an urban or pre-planned model but gradually evolved according to the extension of families and their expansion within the framework of the principles of religion and the culture of the local people due to the necessity of cohesion. Therefore, it is based on Islamic values and on the principle of harmony and other laws and customs. The Islamic system has controlled the relations of society, neighbourhoods and construction, though there have been developments and progress in science and technology, including the emergence of cement then the architecture gradually transformed into concrete structures. Nevertheless, the natural stone used for the facades of architecture has been maintained as shown in Figure 2. 


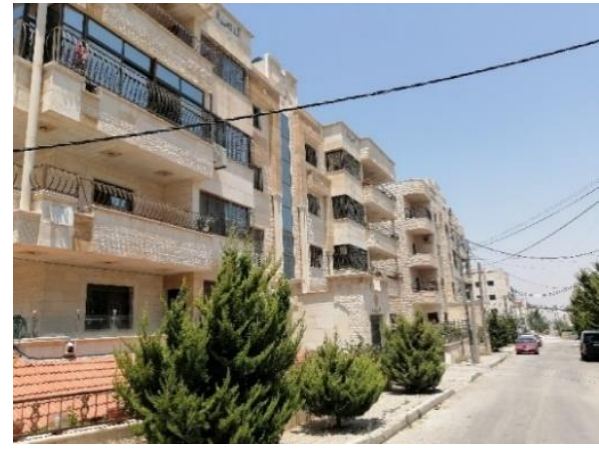

(A) Multi-stories dwelling buildings, which represents contemporary vernacular architecture

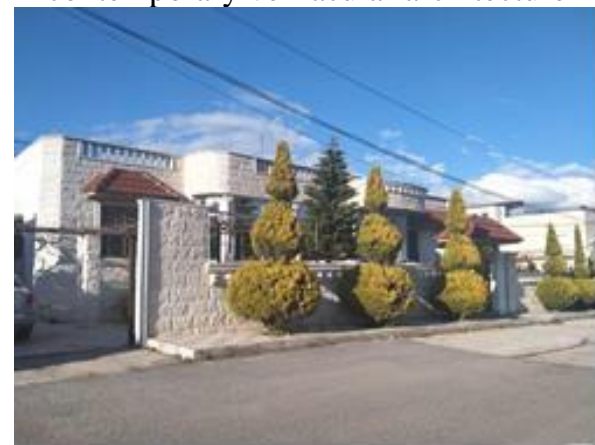

(B) Independent dwelling construction built at the beginning representing contemporary vernacular architecture

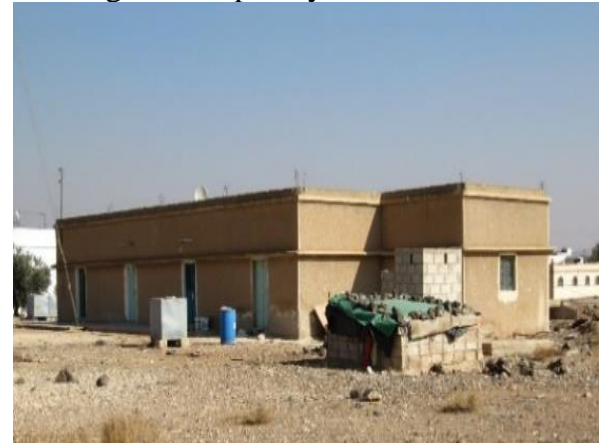

(C) Dwelling house of concrete, which represents vernacular traditional architecture

Figure 2. Types of vernacular dwelling that spread in Jordan. (Source: by the author)

\section{FACTORS THAT EFFECT ON VERNACULAR DWELLING IN JORDAN}

\subsection{Social factors}

Traditional Jordanian architecture is distinguished by dealing with the environment and available materials, the most important of these materials are stone and mud which define identity of construction [5]. It is noticeable that the current design patterns of Jordanian housing heavily depend on the creation of expensive elements and spaces as well as the increasing of the area. Thus, elements are created that do not function efficiently or do not perform any function, such as gaps or dead spaces. The spaces of hospitality in most contemporary dwelling buildings constitute approximately $25 \%$ of the total area of the housing structure with a decrease in use, especially in cities, due to the emergence of many other alternatives, such as wedding halls, clubs and restaurants, which are used for many social events. With development, there has been an enhancement in the concept of housing in the Arab world in general and particularly in Jordan, where new married couples have settled in a separate house away from their parents. This has led to the emergence of so-called dwelling buildings or dwelling neighbourhoods and changes in the size and location of the land and in the quality of finishes and facilities available; however, most types of apartments in Jordan still are not appropriate for the social culture because they are mostly low-income apartments. This type of housing does not reflect the customs and traditions due to the inability to build a house as a result of the price of land and the cost of construction, and many have begun to accept living in apartments. The second model is a dwelling villa or semi-villa, which differ in the different areas of land based on the economic and social conditions of the owner and the desire of the family. Based on the review of various dwelling plots, it was shown that the area of most land on which the villas are constructed ranges between $500 \mathrm{~m}^{2}$ to $1200 \mathrm{~m}^{2}$.

\subsection{The regulatory factors that regulate dwelling construction in Jordan}

The division of land in Jordan depends on the Organized Cities and Villages Law No. (79) of 1966. There are three main zones for dwelling construction in Jordan, which are zone A, zone $\mathrm{B}$ and zone $\mathrm{C}$. This law is responsible on dividing the land into residential plots as shown in Table 1, and through this law, modern buildings will be built in Jordan.

Table 1. The laws on the construction of dwelling buildings based on the system of buildings and organisation in Jordan in 2017

\begin{tabular}{|c|c|c|c|c|}
\hline Zone & $\begin{array}{c}\text { Maximum } \\
\text { number of } \\
\text { stories }\end{array}$ & $\begin{array}{c}\text { Maximum } \\
\text { built-up } \\
\text { area }\end{array}$ & $\begin{array}{l}\text { Minimum } \\
\text { lot size }\end{array}$ & $\begin{array}{l}\text { Minimum } \\
\text { width of } \\
\text { front side }\end{array}$ \\
\hline $\begin{array}{c}\text { Housing } \\
\text { A }\end{array}$ & 4 & $39 \%$ & 1000 sq. m & $25 \mathrm{~m}$ \\
\hline $\begin{array}{c}\text { Housing } \\
\text { B }\end{array}$ & 4 & $45 \%$ & 750 sq. m & $20 \mathrm{~m}$ \\
\hline $\begin{array}{c}\text { Housing } \\
\text { C }\end{array}$ & 4 & $51 \%$ & 500 sq. $\mathrm{m}$ & $18 \mathrm{~m}$ \\
\hline $\begin{array}{c}\text { Rural } \\
\text { Dwelling }\end{array}$ & 4 & $30 \%$ & 2000 sq. m & $30 \mathrm{~m}$ \\
\hline
\end{tabular}

\subsection{Economic factors}

Includes providing for families' needs to achieve environmental and social satisfaction and is commensurate with its economic conditions to ensure easy and low-cost construction, operation and maintenance. This type of housing requires the design to achieve the basic functions of a dwelling building, which include common functions between people and spaces. This basic function is supplemented with necessary and desirable functions, and these functions collectively address the activities performed by the occupants. In view of the social and economic changes that have had major impacts on all aspects of life in the current century, it is important to move towards the concept of housing facilitation and to adopt the trend of so-called affordable housing. Affordable housing is housing that meets the requirements of the family without increasing or decreasing the limits of the potential and the level of household income. Therefore, this provides families with the basic objective of housing. The concept of facilitation extends to all aspects from the plot of land to the elements and components of the dwelling building, 
the method and materials used for its construction and even equipment. There are several economic factors that affected the cost of the dwelling building in Jordan, including successive migrations from neighbouring countries from Palestine, Iraq and Syria, and an increase in natural population growth, where it was $2.4 \%$ [6]. Which led to an increase in land prices, which varies from city to city where it was the most expensive in major cities such as Amman and Zarqa, which led to appear multi-story housing in the beginning of the nineties of the last century, and this led to an increase in the cost of building materials, Construction costs for limestone facade amounted to $250 \mathrm{JD}$ per square meter to $500 \mathrm{JD}$ depending on the price of lands and quality of construction. There is extra cost reaches to $12 \%$ for additional water and energy-saving features [2].

\subsection{Water resources and energy factors}

As for Jordan, the average monthly costs for electricity needs ranged around 38Jd, while one of the World Bank reports indicated that the average per capita gross national income, according to purchasing power parity is 533Jd per month, The average is close to $490 \mathrm{Jd}$, and therefore the energy cost to the citizen is estimated at about $7.2 \%$ of the total income [7].

Jordan is considered to be one of the world's 10 poorest countries in water resources, whereas its population growth rate is about $2.9 \%$, the 9th highest in the world. The available renewable water resources are dropping drastically to an annual per capita share of $160 \mathrm{~m}^{3}$ in recent years, compared to $3,600 \mathrm{~m} / \mathrm{cap} / \mathrm{a}$ in 1946 . While Jordan is currently suffering from a decrease in domestic per capita share reaching 86 liters/capita/day, this trend is expected to continue if no additional resources are developed. Jordan is striving not only to maintain domestic consumption at its current levels, but also to boost it to internationally accepted standards, at $150 \mathrm{1} / \mathrm{c} / \mathrm{d}$ [8].

Since Jordan is one of the poorest countries in water sources, and the solar resource in the Kingdom is available, as it has 333 solar days, which is equivalent to 8 sunny hours per day of the year. Therefore, solar heating systems and water harvesting that are used in green buildings will be successful and effective. The citizen may recover the extra costs during construction on these two items within a few years, not to exceed five years.

\subsection{Traditional architecture and the local environment}

Traditional architecture addresses environmental problems, such as climatic conditions, functional, social and religious requirement [9]. Vernacular architecture in Jordan is flexible architecture because it dealt with each region within its environmental conditions, its functional needs and building materials, for example, dealing with the semi-desert region in southern and eastern Jordan, different from dealing with the mountainous and coastal areas in central and northern Jordan [10]. Vernacular architecture is a harmony of human, community and the built environment [11].

Concept of sustainability was applied to old communities in Jordan because the environment was the source of their lives. Their interactions with the surrounding environment and the optimal utilisation of natural resources were ways to ensure that they remained on the land in, as shown in Figure 3.

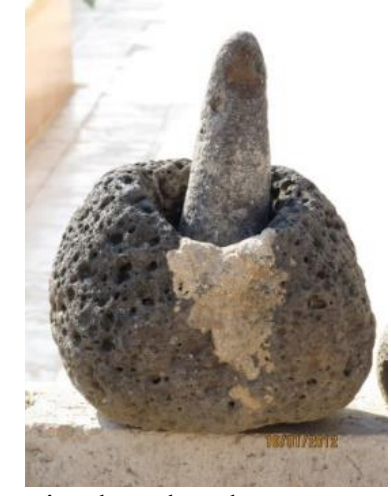

(A) Picture showing how basalt stone was used as a grain

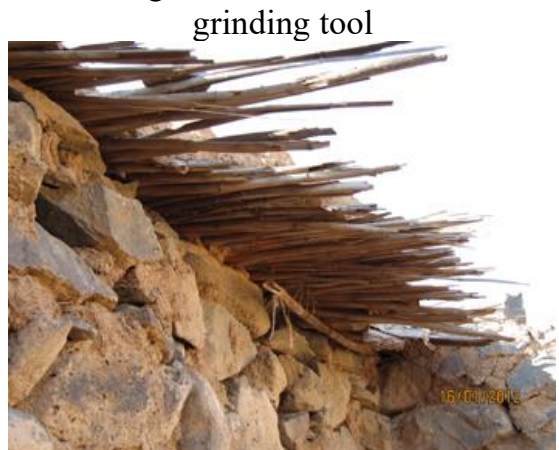

(B) Picture showing roofs in heritage houses where natural materials were used

Figure 3. Dealing of Jordanian society with nature in different ways. (Source: by the author)

\section{THE EMERGENCE OF GREEN ARCHITECTURE GLOBALLY}

Green architecture, the most modern trend in architectural thought, deals with the relationship between architecture and the environment. It is a general term that describes environmentally conscious design techniques in the field of architecture. Green architecture can be defined as architecture responsive to the environment in which architecture is designed in harmony with the surroundings and is adapted to the lifestyles of its users. 'Green building implementation is known as an integrating process that consists of building design, construction, operation, maintenance or renovations, and recycling or demolition by considering environmental conditions' [12]

\subsection{The most important standards of green architecture that 'LEED' seeks to achieve}

The green building design process begins with an understanding of the location altogether its beauties and complexities. An ecological approach to style aims to integrate the systems being introduced with the prevailing on-site ecological functions. the subsequent points summarize key strategies and techniques which are related to the main elements of green building design, which are Sustainable Site Design, conservation and Quality, Energy and Environment, Indoor Environmental Quality and Conservation of Materials as shown in Figure 4. This information supports of the utilization of the USGBC 'LEED' Green Building scoring system but focuses on methods instead of specific solutions, which are often site-specific and can vary from project to project [13]. 


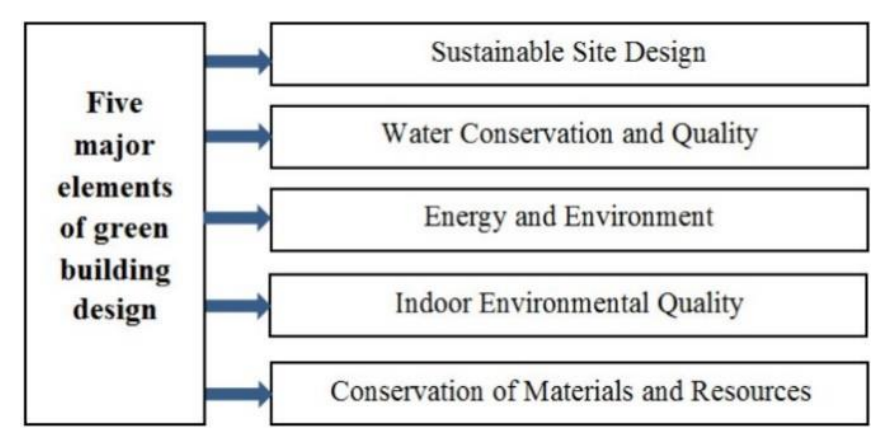

Figure 4. Elements of green building design [13]

Based on the summaries and publications of the standards of green architecture presented by 'LEED', its criteria are summarised as follows:

1. Energy conservation: The architecture should be designed and constructed in a manner in which the need for fossil fuels and reliance on natural energies is reduced.

2. Use environment-friendly designs with available technology: Energy use may be reduced by $70 \%$ in dwelling architecture and by $60 \%$ in commercial architecture. Electricity consumption can also be reduced using photovoltaic solar cells that produce electricity directly from sunlight.

3. Adapt to the climate through create an internal atmosphere suitable for comfort.

4. Respect for the site: The main objective of this principle is to specify the architecture site, which does not involve fundamental changes in the parameters of the site. The site returns to its normal state if the architecture is removed or moved from the site.

5. Insulation and construction: Proper insulation contributes to energy bills in the future. Therefore, many new architecture structures are isolated using recyclable materials, such as blown glass fibre.

6. Home appliances: Have a low flow of shower faucets or taps of compressor toilets, ensure that air conditioning units are isolated and completely clean and search for instant gas stoves or energy-saving water heaters.

7. Flooring: Instead of using expensive hardwoods that cause deforestation, there are many inexpensive and beautiful bamboo alternatives that are technically not wood but are one of the toughest flooring materials that can easily be replaced.

8. Coating: Coating is considered an alternative environmental material rather than oil and rubber.

9. Solar energy: Solar energy tends to be an expensive investment initially, but it is more beneficial compared to monthly energy bills. Consider solar home appliances in the sense of investing in thick or split windows or in more complex photovoltaic cells.

10. Parks and landscapes: It helps to find a common green space of plants that require little irrigation.

\subsection{Objectives of the 'LEED' system and its mode of operation}

In Jordan, many conferences were held to discuss environmental architecture, which led to work to revive vernacular environmental architecture in societies. With the publication of the Green Architecture Manual by the Ministry of Public Works in 2010 the government began moving towards green architecture. The Green building guideline contains parameters that is suitable for Jordan's climate, resources, legislation and policies instrument. This Guideline is attached with rating system that is connected to an incentive scheme given by the government [14].

This is to encourage architects to apply green architecture concepts in their designs, and one of the results of the study was the work of the Royal Scientific Society entitled "Green Building Development in Jordan".

It was found that $44 \%$ of Jordanian society is only familiar with water and energy saving mechanisms and only $22 \%$ work according to engineering plans.

There is a correlation between the geographical area and the level of awareness where companies located in urban areas such as Amman, Irbid and Zarqa are keen to apply the concepts of green architecture more than others.

In Jordan, studies have indicated that economic status influences on green architecture practices and applications, studies showed that around $55 \%$ of people are aware of water and energy conservation needs, while 33\% saw that green applications in housing as costly and not competitive [15].

Leadership in Energy and Environmental Design (LEED) may be a green building certification program developed by U.S. Green Building Council (USGBC) it includes a group of rating systems for the planning, construction, operation, and maintenance of green buildings and home that aims to assist owners and operators of buildings be responsible on the environment and to help them how to use resources. 'LEED' effectively serves as the de facto benchmark for the design, construction, and operation of high-performance green buildings with over 92,000 projects using 'LEED' and 2.2 million square feet of building space certified under 'LEED' daily' [16]. To obtain an 'LEED' certificate, the 'LEED' standards and procedures must be applied and the fees paid. Ordinary people will not complete this process and will continue to follow the requirements of their vernacular architecture; however, Jordanian society can apply the concepts of green architecture without sponsoring any international organisations, such as the 'LEED'. These international organisations only relate to architecture that belongs to official or government institutions. The (LEED) program has requirements and criteria that must be met in the building to get points in order to obtain a rating as shown in Figure 5.

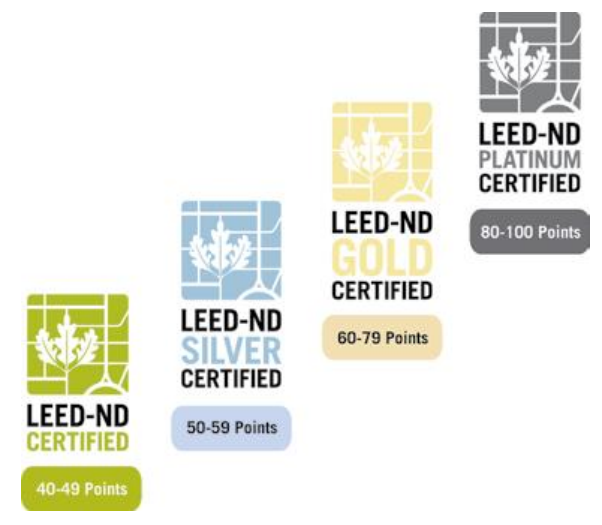

Figure 5. The degrees that the green architecture gets within the system "LEED" [17]

One of the goals of architecture is usually to be a community environment architecture, especially in housing construction, because the foremost demanding is that the dwelling each community has its own building requirements and builds according to its capabilities and material ability and the local 
construction method in its country and the materials available to it, culture differences may lead to unique occupancy patterns even for buildings with similar functions too, which can eventually lead to different building design code settings related to occupancy [18].

Citizens in Jordan try to decrease the cost of construction as possible, then observing the concept of green architecture, and thus the citizen applies vernacular architecture that's compatible with the environment and meets the requirements of the environment, and doesn't seek green architecture with a certificate from any organization, whether global or local. For architects, it is necessary to work toward the development of architecture with all its concepts because sustainable architecture does not necessarily involve the adoption and use of high-cost technologies; however, it aims to provide the simplest and lowest cost of technologies that are most efficient and to take many of the design factors into account, such as economic, social and cultural factors. It must also be simple to execute, comprehensible to local operators, and use locally available materials and the selected technology should also be appropriate for use in different types of buildings [19]. It is difficult to deal with the proposed model and the criteria imposed by some organizations concerned with green buildings as a practical application of dwelling in all countries of the world due to their high costs and the difficulty of apply them, as you can see Figure 6.

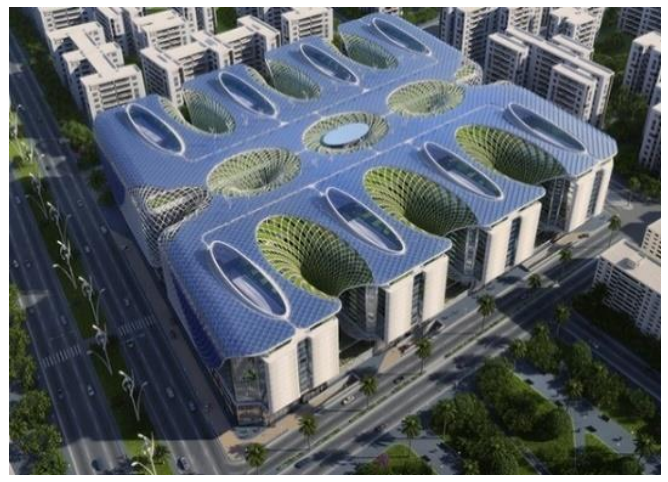

Figure 6. One of the proposed models for green building in Egypt with cost of \$ 590 million [20]

\section{THE CASE STUDY}

The concept of green vernacular environmental construction was implemented in the city of Irbid, Jordan, which was designed by the author in an attempt to apply green architecture in line with the vernacular architecture.

Traditional housing reflects the needs of its residents and their control over housing. The elements and spaces that perform the function are in line with the requirements and activities, whether they are intended for reception with the independence and privacy provided in accordance with established customs and traditions or sleeping spaces and service elements. This is linked to the area of land needed for construction, which is often limited in the clear realisation of the economy in the cost of land value and is one of the most prominent factors in the high cost of housing in Jordan. Designing a contemporary dwelling building and traditional vernacular architecture in Jordan has been completed so that there is a vernacular green environmental structure within the economic capacity of the society as well as to achieve the green design of architecture and the requirements of green architecture. Vernacular architecture and modern dwelling architecture in Jordan do not depart from the concept of environmental architecture in general and green architecture in particular. For instance, 'buildings that are designed in accordance with a community's culture, lifestyle and the physical and climatic conditions of such communities are called vernacular architecture. Vernacular architecture establishes a harmonious relationship between the climate, architecture and people. Vernacular contributions of sustainability to architectural designs are steadily increasing in parallel with developments in technology' [21].

\subsection{Green environmental considerations of the case study}

The focusing of designer in this project was to apply some of the concepts of green architecture to be compatible with the budget of the owner of buildings according to the vernacular architectural style:

1. The designer attempted to divide the land into suitable plots to construct semi-villas on a land of $850 \mathrm{~m}^{2}$ within the provisions of construction and legislation in Jordan as shown in Figure 7.

2. Attempt to use vernacular architecture materials as much as possible considering the environmental conditions.

3. Emphasise isolating the architectural structure for energy conservation, especially in Jordan, where there are differences in temperature per day.

4. Provide the required space in the design to satisfy the owners of building.

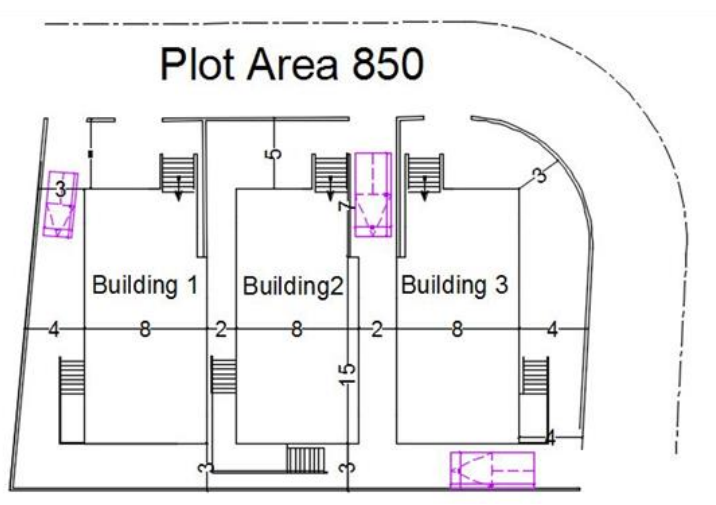

Figure 7. Land with a single dwelling building. (Source, by the author)

\subsection{Applied criteria in the case study}

In accordance with these objectives which affect the environmental, functional and aesthetic quality as well as the future values of construction and architectural products, there must be a set of priorities in the design to obtain a sustainable architectural product Vernacular dwelling architecture in Jordan as shown in Figure 8. These criteria are as follows:

(1). Distribute three independent small villas to reduce the price of land, this land is used by some people to build one villa. The plot is divided into three equal parts. Three semivillas with an area of $250 \mathrm{~m}^{2}$ were designed for the single dwelling building. Therefore, the benefit of the plot and the price of the plot of land were distributed to the owners of the three villas.

(2). Link the site to the environmental design approach and also take into account the regulations and laws that concern the architecture. The designer should reach for the independence 
of each architectural structure. Create an external yard to grant the required privacy as a social condition inherited from the customs and traditions.

(3). Obtain the quality and required spaces in the architecture in a case in which the architecture is divided according to the needs of the family spaces with an area of 220 $\mathrm{m}^{2}$ without an increase or a decrease. The design is based on the duplex system. On the ground floor, there is a salon for living rooms, reception rooms, the kitchen and the guest toilet. The first floor has three bedrooms and two bathrooms. These rooms have one master room, and this is suitable for the requirements of dwelling construction in Jordan.

(4). Find the possible spaces and external squares in addition to the elements of the coordination of the site. An external yard is provided for each house as a parking and as an area for events to entertain and receive guests, especially on the occasions of Ramadan and holidays, to suit the design based on the climatic factor of air traffic. These squares are the work of the courtyard in heritage architecture in (Beladassham) and in desert areas.

(5). Ensure flexibility and versatility of spaces. Although spaces are allocated to perform specific functions in the traditional design of the house, rooms facing the south are used more during the cold winter period because these spaces are characterized by sunbathing and natural heating. On the other hand, the east and north oriented areas are more used during the summer period.

(6). Find climate solutions to achieve a healthy environmental space in terms of good ventilation, natural lighting and the provision of comfort space. The aim was to use the moving air which come from opening at the top of the staircase (working as wind catcher), and the air comes from a door on the southwest. As a result of this air movement, it is well-ventilated in the summer. Double windows and a space between the glass and other is $12 \mathrm{~mm}$ have been installed with the use of insulated abrasions at a 5-mm thickness. For winter, some of the balconies were designed and covered with glass so that the heated air during the day comes inside the house. The opening at the top of the staircase is closed in the winter and allows sunshine and natural sufficiency

(7). Use construction materials and traditional vernacular architecture techniques.

(8). Using the cells and securing the electricity power at the equivalent of $900 \mathrm{~km}$ watts annually, which saves in the electricity bill, knowing that these cells need an area of approximately 35 square meters, and this is difficult to apply to multi-story buildings that contain ten apartments according to the Jordanian regulation law, meaning we need to 350 square meters, in addition to mandatory provision of 10 water tanks on the roof of the building, knowing that the roof is for all of dwelling apartments.

(9). Identify the right place to harvest rainwater and to reuse it again by collecting rainwater on the roof of the structure in a large water tank with a capacity of 30 cubic meters. Next, pump this water to the water tanks for use, and it is completely recycled to be used as grey water to irrigate the green areas.

(10). Isolate the architectural structure so it is completely isolated in its exterior with a 5-cm thick polystyrene.

(11). Use environmentally friendly paints, such as Jotun products.

(12). Sustainable architecture at the construction stage is expected to cost more than normal architecture but is economically after some of years.

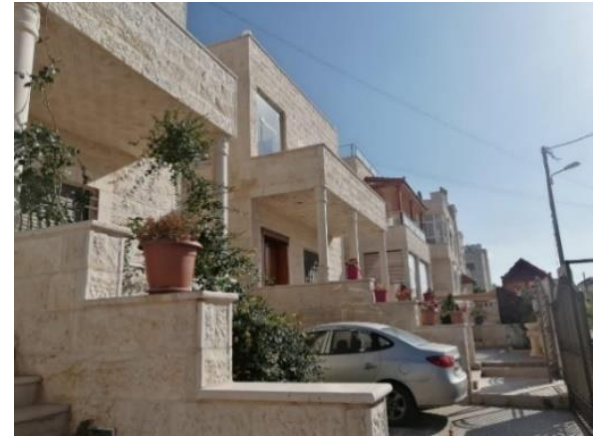

(A) The result of three villas distribution where the green building standards were applied

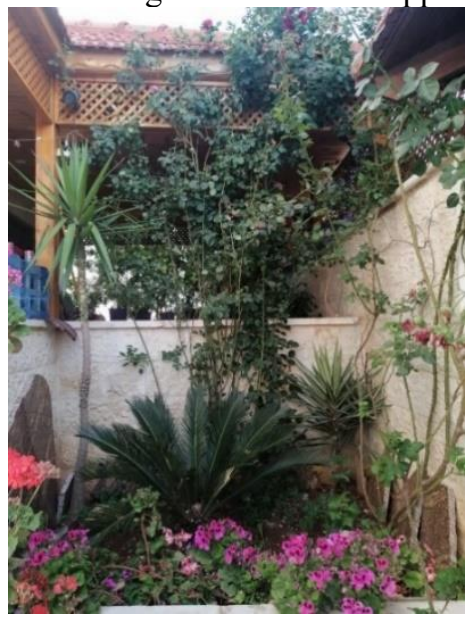

(B) Outside landscape helped in air movement and in find simple sessions in the yard

Figure 8. Results of ideas that have been applied in the case study. (Source, by the author)

\section{RESULTS}

This research yielded set of results, which includes:

(1). Conventional vernacular architecture is capable of providing realistic environmental solutions. It is not an antithesis of green architecture but it is integrated scientific approach reflects society with its variables and aspirations and can be developed.

(2). Sustainability from a technological point of view does not mean the imitation of ancient and historical techniques. It is the harmonization between authenticity and modernity, between beauty and mind and between economy and wellbeing to serve different users and their aspirations for development

(3). Construction technology from the sustainability perspective reflects the reciprocal relationship between the intellectual and cultural development of society and technological development.

(4). Modern developments in technology and using of energy resources and advanced architectural materials have helped to find solutions for traditional dwelling architecture.

\section{CONCLUSIONS AND RECOMMENDATION}

The idea of green building in Jordan can be developed by linking it with vernacular architecture within the building laws, Jordanian capita income, building materials so that the topic of green architecture applicable in all countries and is not 
limited to the rich, but green architecture must become a realistic community architecture.

The awareness of the user about the health and psychological benefits with using green buildings must be risen, especially after increasing the realistic knowledge culture of the designer and the user in the lock-down period in COVID-19.

This requires attention from architects to improve their designs according to sustainable green architecture and apply their designs.

- Green building architecture accommodates its residents in all circumstances and is not limited to the Thermal comfort and saving in energy only, but also designer must find places for entertainment inside the house with the flexibility of the functional space.

- The use of negative solar design (guidance, ratios, insulation, shading, natural lighting and ventilation, high efficiency wall openings and ceilings, etc.) to reduce dependence on mechanical and electrical systems is indispensable in environmental architectural design.

Produce and update architectural products and materials with appropriate specifications for green building application and sustainability.

- Local governments should develop laws, legislations and architecture codes commensurate with the potential of the state and the possibility of its citizens to contribute to the development of green architecture.

\section{REFERENCES}

[1] Steele, J. (1997). Architecture Today. London: Phaidon Press. p. 248.

[2] Center for the Study of the Built Environment (CSBE) in association with Uraiqat Architects. (2020). Contemporary Rural Dwellings in Jordan: Conception, Construction, Habitation. The Case Study of Umm alYanabi' Town, Jordan. https://www.csbe.org/contemporary-rural-dwellings-injordan, accessed on May 12, 2020.

[3] National Council for Family Affairs. (2018). Jordanian Family Report, $\quad$ p. 13 http://ncfa.org.jo:85/NCFA/sites/default/files/Publicatio ns/family-report.pdf, accessed on May 12, 2020.

[4] Alzoubi, H.H., Almalkawi, A.T. (2019). A comparative study for the traditional and modern houses in terms of thermal comfort and energy consumption in Umm Qais city. Jordan. Journal of Ecological Engineering, 20(5): 14-22. https://doi.org/10.12911/22998993/105324

[5] Salman, M. (2018). Sustainability and vernacular architecture: rethinking what identity is. In Urban and Architectural Heritage Conservation within Sustainability. https://doi.org/10.5772/intechopen.82025

[6] Salameh, E., Shteiwi, M., Al Raggad, M. (2018). Water Resources of Jordan: Political, Social and Economic Implications of Scarce Water Resources. Springer International Publishing. https://doi.org/10.1007/978-3319-77748-1

[7] Khdoor, A. (2019). Average burden of electricity in Jordan, Lebanon, Iraq and Syria. Journalist report (in Arabic). https://sptnkne.ws/nyA9, accessed on May 12, 2020.

[8] Ababsa, M., Kohlmayer, C. (2013). Atlas of Jordan:
History, Territories and Society. Beyrouth, Liban: Institut français du Proche-Orient, 2013.

[9] Daradkeh, S. (2009). The green buildings, the concept and the application in the traditional Architectures in the near east. (Master's Degree in Architecture), University of Jordan, Jordan. https://theses.ju.edu.jo/Original_Abstract/JUF0674320. pdf, accessed on May 12, 2020.

[10] Elshimy, H., Samir, N. (2017). Green building between tradition and modernity study comparative analysis between conventional methods and updated styles of design and architecture processors. Renewable Energy and Sustainable Development, 3(1): 155-163. http://dx.doi.org/10.21622/resd.2017.03.1.155

[11] Creang, E., Ciotoiu, I., Gheorghiu, D., Nash, G. (2010). Vernacular architecture as a model for contemporary design. WIT Transactions on Ecology and the Environment, 128: 157-171. https://doi.org/10.2495/ARC100141

[12] Basten, V., Berawi, M.A., Latief, Y., Crévits, I. (2018). Building incentive structure in the context of green building implementation: from the local government perspective. Journal of Design and Built Environment, 18(2): 37-45.

[13] Ragheb, A., El-Shimy, H., Ragheb, G. (2016). Green architecture: A concept of sustainability. Procedia-Social and Behavioral Sciences, 216: 778-787. https://doi.org/10.1016/j.sbspro.2015.12.075

[14] Awadallah, T., Habet, S., Mahasneh, A., Adas, H. (2011). Green Building Guideline of Jordan. Green Building, 20(6).

[15] Royal Scientific Society. (2013). Green Building Development in Jordan. Published in 2013 by the Royal Scientific Society of Jordan and the Friedrich-EbertStiftung Amman Office. ISBN: 978-9957-484-37-8.

[16] NAPA. (2018). Asphalt Pavements. LEED v4: Credits \& Opportunities. Retrieved from USA. http://www.asphaltpavement.org/PDFs/Sustainability/SI P001\%20Asphalt\%20Pavements\%20LEED\%20v4.pdf, accessed on May 12, 2020.

[17] Raimi, M., Welch, A., Benfield, K. (2011). A Citizen's Guide to LEED for Neighborhood Development: How to Tell If Development Is Smart and Green. https://www.nrdc.org/sites/default/files/citizens_guide LEED-ND.pdf, accessed on May 12, 2020.

[18] Hu, S., Yan, D., Azar, E.A., Guo, F. (2020). A systematic review of occupant behavior in building energy policy. Building and Environment, 175: 106807. https://doi.org/10.1016/j.buildenv.2020.106807

[19] Aldeek, A. (2020). Green architecture and sustainability in the complex transformation of the built urban environment in Jordan. International Journal of Design \& Nature and Ecodynamics, 15(1): 113-120. https://doi.org/10.18280/ijdne.150115

[20] Gabr, A. (2015). Wamda. Retrieved from https://www.wamda.com/memakersge/2015/10/5ecofriendly-developments-in-mena, accessed on May 12 , 2020.

[21] Salgın, B., Bayram, Ö.F., Akgün, A., Agyekum, K. (2017). Sustainable features of vernacular architecture: Housing of Eastern Black Sea Region as a case study. Paper Presented at the Arts., 6(3): 11. https://doi.org/10.3390/arts603001 